\title{
Nota
}

\section{METHODS TO QUANTIFY NICKEL IN SOILS AND PLANT TISSUES}

\author{
Bruna Wurr Rodak $^{(1) *}$, Milton Ferreira de Moraes $^{(2,3)}$, João Augusto Lopes Pascoalino(3), \\ Adilson de Oliveira Junior ${ }^{(4)}$, Cesar de Castro $^{(4)}$ and Volnei Pauletti( ${ }^{(3)}$
}

(1) Universidade Federal de Lavras, Departamento de Ciência do Solo, Lavras, Minas Gerais, Brasil.

(2) Universidade Federal de Mato Grosso, Instituto de Ciências Exatas e da Terra, Campus Universitário do Araguaia, Barra do Garças, Mato Grosso, Brasil.

(3) Universidade Federal do Paraná, Departamento de Ciência do Solo e Engenharia Agrícola, Curitiba, Paraná, Brasil.

(4) Empresa Brasileira de Pesquisa Agropecuária, Centro Nacional de Pesquisa em Soja, Londrina, Paraná, Brasil.

* Corresponding author.

E-mail: brunawurrrodak@hotmail.com

\begin{abstract}
In comparison with other micronutrients, the levels of nickel $(\mathrm{Ni})$ available in soils and plant tissues are very low, making quantification very difficult. The objective of this paper is to present optimized determination methods of $\mathrm{Ni}$ availability in soils by extractants and total content in plant tissues for routine commercial laboratory analyses. Samples of natural and agricultural soils were processed and analyzed by Mehlich-1 extraction and by DTPA. To quantify Ni in the plant tissues, samples were digested with nitric acid in a closed system in a microwave oven. The measurement was performed by inductively coupled plasma/optical emission spectrometry (ICP-OES). There was a positive and significant correlation between the levels of available $\mathrm{Ni}$ in the soils subjected to Mehlich-1 and DTPA extraction, while for plant tissue samples the Ni levels recovered were high and similar to the reference materials. The availability of $\mathrm{Ni}$ in some of the natural soil and plant tissue samples were lower than the limits of quantification. Concentrations of this micronutrient were higher in the soil samples in which $\mathrm{Ni}$ had been applied. Nickel concentration differed in the plant parts analyzed, with highest levels in the grains of soybean. The grain, in comparison with the shoot and leaf concentrations, were better correlated with the soil available levels for both extractants. The methods described in this article were efficient in quantifying $\mathrm{Ni}$ and can be used for routine laboratory analysis of soils and plant tissues.
\end{abstract}

Keywords: micronutrient, availability, Mehlich-1, DTPA, ICP-OES. 


\title{
RESUMO: MÉTODOS DE QUANTIFICAÇÃO DE NÍQUEL EM SOLO E TECIDO VEGETAL
}

\begin{abstract}
Em comparação a outros micronutrientes, os teores de níquel (Ni) disponíveis no solo e tecido vegetal são bastante baixos, com alto grau de dificuldade para a quantificação deles. $O$ objetivo deste estudo foi apresentar métodos otimizados de determinação da disponibilidade de Ni em solos com extratores e teor total em tecido vegetal para análises de rotina em laboratórios comerciais. Foram processadas e analisadas amostras de solos naturais e agrícolas com extração pelo extrator Mehlich-1 e por DTPA. Para quantificar o Ni no tecido vegetal, as amostras foram digeridas com ácido nítrico em sistema fechado em forno micro-ondas. A determinação foi realizada em espectrômetro de emissão óptica com plasma induzido (ICP-OES). Houve correlação positiva e significativa entre os teores disponíveis de Ni nos solos extraídos em Mehlich-1 e DTPA, enquanto, para o tecido vegetal os teores de Ni recuperados foram altos e similares aos materiais de referência. A disponibilidade de Ni em algumas amostras de solos naturais e tecido vegetal foram inferiores aos limites de quantificação. Os teores desse micronutriente foram maiores em amostras de solo em que houve fornecimento de Ni. A concentração de Ni difere nas partes vegetais analisadas, e os grãos de soja apresentaram os maiores teores. Os grãos, em relação às partes aérea e foliar, têm melhor correlação com os teores disponíveis no solo para ambos extratores. Os métodos descritos nesta pesquisa foram eficientes na quantificação de Ni e podem ser adotados em laboratórios de rotina de solos e tecido vegetal.
\end{abstract}

Palavras-chave: micronutriente, disponibilidade, Mehlich-1, DTPA, ICP-OES.

\section{INTRODUCTION}

Nickel (Ni) is the $23^{\circ}$ most abundant element in the Earth's crust. The total concentration of $\mathrm{Ni}$ in soils varies widely, from 5 to $500 \mathrm{mg} \mathrm{kg}^{-1}$, with an average value of $40 \mathrm{mg} \mathrm{kg}^{-1}$ (Liu et al., 2011). Uren (1992) reported that the available amounts only correspond to $0.001 \%$ of the total amounts, and according to Vanselow (1966), most of the time the available levels are lower than $1 \mathrm{mg} \mathrm{dm}^{-3}$. The leaf concentrations of $\mathrm{Ni}$ in plants grown in uncontaminated soils are generally between 0.05 and $5 \mathrm{mg} \mathrm{kg}{ }^{-1}$, but most frequently nearer to the lower limit of this range (Brooks, 1980; Welch, 1981). Therefore, Ni can be classified as a trace element in both soils and plants.

The difficulty of quantification due to the lack of devices that are sufficiently sensitive to detect $\mathrm{Ni}$ is one of the reasons this element was the last one included in the list of micronutrients. Its essentiality, as demonstrated by Brown et al. (1987) and Eskew et al. $(1983,1984)$, is due to the fact that $\mathrm{Ni}$ is a structural constituent of the enzyme urease, which hydrolytically turns urea $\left[\mathrm{CO}\left(\mathrm{NH}_{2}\right)_{2}\right]$ into ammonia $\left(\mathrm{NH}_{3}\right)$ and carbon dioxide $\left(\mathrm{CO}_{2}\right)$ (Dixon et al., 1975).

Nickel was recently included in Brazilian regulations on fertilizers by the Normative Instruction $\mathrm{N}^{0} 5$ of February 23, 2007, issued by the Ministry of Agriculture (Brasil, 2014), but there are so far no official recommendations for its use in fertilization programs. Formulating adequate recommendations depends on understanding the effects of the available levels in agricultural soils and plant tissues, and thus on standardization of suitable methods to measure these levels.
There are various analytic methods to measure $\mathrm{Ni}$ concentrations. Among them, the most promising are inductively coupled plasma with mass spectrometry (ICP-MS), inductively coupled plasma with optical emission spectrometry (ICP-OES), atomic fluorescence spectrometry (AFS), X-ray fluorescence (XRF), polarography, voltammetry, flame atomic absorption spectrometry (FAAS), and graphite furnace atomic absorption spectrometry (GFAAS) (Freschi et al., 2000). Among those techniques, some are very expensive and also involve instruments not commonly found in laboratories for routine analyses of soils and plant tissues. Therefore, it is necessary to develop less expensive and more accessible methods for extraction and digestion, to enable $\mathrm{Ni}$ quantification in laboratories and provide farmers with well-based recommendations and technical assistance.

The objective of this scientific note is to present optimized methods for $\mathrm{Ni}$ quantification in plant tissues and its availability in soils, using extraction and digestion techniques commonly employed in routine laboratory analyses in Brazil.

\section{MATERIAL AND METHODS}

The study was conducted at the Soil and Plant Tissue Laboratory of Brazilian Corporation of Agricultural Research, National Soybean Research Center, located in Londrina, Paraná, Brazil.

Samples of 14 soils were collected from the $0-20 \mathrm{~cm}$ layer (Table 1), as well as samples of soybean plant tissues (Glycine max [L.] Merrill) (grains, shoot and leaves). Some of these soil and plant samples came from experiments under 
controlled conditions where the plants were treated with $\mathrm{Ni}$ doses of $0.0,0.2,0.4,0.5,0.8,1.0$, and $5.0 \mathrm{mg} \mathrm{dm}^{-3}$ incorporated in the soil, in which a compilation of the mean Ni levels from these experiments was performed (Rodak, 2014).

The soil and plant tissue samples were dried in a chamber with forced air circulation, at approximately 60 to $65^{\circ} \mathrm{C}$, for $72 \mathrm{~h}$. Dried samples were then ground, sieved, and stored in plastic containers until analysis.

The Ni concentrations in the samples were determined by ICP-OES with a Perkin Elmer Optima 8300 DV spectrometer at a wavelength of $231.604 \mathrm{~nm}$. Calibration solutions were prepared from suitable dilutions of a stock solution containing $1,000 \mathrm{mg} \mathrm{L}^{-1}$ of $\mathrm{Ni}$. Calibration curves were plotted from $\mathrm{Ni}$ concentrations of $0.015,0.050,0.10,0.25$, $0.50,1.00$, and $2.00 \mathrm{mg} \mathrm{L}^{-1}$ to quantify the availability in the soil, and $0.0075,0.015,0.075,0.15,0.25,0.50$, and $1.00 \mathrm{mg} \mathrm{L}^{-1}$ for the plant tissue samples. The smaller the concentration range of the calibration curve, the more sensitive will be the determination of low Ni concentrations. Thus, when the samples did not tend to high Ni concentrations, the soil curve was used up to a concentration of $1.0 \mathrm{mg} \mathrm{L}^{-1}$.

Reference samples of soil $\left(\mathrm{BCR}^{\circledR}-142 \mathrm{R}\right)$ and plant tissue (Trifolium repens $\mathrm{L}$. BCR ${ }^{\circledR}-402$ and Lichen BCR $^{\circledR}$ - 482), certified by the European Commission - Joint Research Centre, Institute for Reference Materials and Measurements, and grain samples (Vicia fava IPE 903 and Phaseolus vulgaris IPE 192), certified by the Wageningen Evaluating Programs for Analytical Laboratories, International Plant-Analytical Exchange, were used to ensure the quality control of the analyses and adjustment of the methods.

The Pearson linear test was used to calculate the correlations of the available levels of $\mathrm{Ni}$ in the soil and concentrations in the shoots, grains and leaf samples, using Statistica 7 software (Stat Soft, 2004).

\section{Soil analysis}

\section{Availability of Ni with Mehlich-1 digestion}

Extraction method as described by Embrapa (2009). Samples (volume of $5 \mathrm{~cm}^{3}$ ) were added to $50 \mathrm{~mL}$ of Mehlich-1 extractant solution. Then the samples were stirred for $10 \mathrm{~min}$ at $200 \mathrm{rpm}$, after which the suspension was left to rest for $16 \mathrm{~h}$ to decant and an aliquot of the sample was submitted to ICP-OES to quantify the Ni content. Mehlich-1 extractant solution consisted of a mixture of hydrochloric acid $\left(\mathrm{HCl} 0.05 \mathrm{~mol} \mathrm{~L}^{-1}\right)$ and sulfuric acid $\left(\mathrm{H}_{2} \mathrm{SO}_{4} 0.012 \mathrm{~mol} \mathrm{~L}^{-1}\right)$.

\section{Availability of Ni with DTPA digestion}

Extraction method as described by Raij et al. (2001). Samples of a volume of $5 \mathrm{~cm}^{3}$ were added
Table 1. Classification and location of soil samples from the $0-20 \mathrm{~cm}$ layer

\begin{tabular}{|c|c|c|}
\hline \multirow{2}{*}{ Soil classification $^{(1)}$} & \multicolumn{2}{|c|}{ Location } \\
\hline & County & State \\
\hline $\begin{array}{l}\text { Latossolo Vermelo-Amarelo } \\
\text { distrófico típico (LVAd) }\end{array}$ & Balsas & Maranhão \\
\hline $\begin{array}{l}\text { Latossolo Amarelo distrófico } \\
\text { típico (LAd) }\end{array}$ & $\begin{array}{l}\text { Luiz Eduardo } \\
\text { Magalhães }\end{array}$ & Bahia \\
\hline $\begin{array}{l}\text { Latossolo Vermelho distrófico } \\
\text { típico (LVd) [1] }\end{array}$ & $\begin{array}{l}\text { Primavera do } \\
\text { Leste }\end{array}$ & Mato Grosso \\
\hline $\begin{array}{l}\text { Latossolo Vermelho distrófico } \\
\text { típico (LVd) [2] }\end{array}$ & Rio Verde & Goiás \\
\hline $\begin{array}{l}\text { Latossolo Bruno alumínico } \\
\text { típico (LBa) }\end{array}$ & Campo Novo & $\begin{array}{l}\text { Rio Grande } \\
\text { do Sul }\end{array}$ \\
\hline $\begin{array}{l}\text { Latossolo Vermelho distrófico } \\
\text { húmico (LVd) [3] }\end{array}$ & Coxilha & $\begin{array}{l}\text { Rio Grande } \\
\text { do Sul }\end{array}$ \\
\hline $\begin{array}{l}\text { Latossolo Vermelho } \\
\text { distroférrico típico (LVdf) [1] }\end{array}$ & Londrina & Paraná \\
\hline $\begin{array}{l}\text { Latossolo Vermelho } \\
\text { eutroférrico típico (LVef) }\end{array}$ & Palotina & Paraná \\
\hline $\begin{array}{l}\text { Latossolo Vermelho distrófico } \\
\text { típico (LVd) [4] }\end{array}$ & Iporã & Paraná \\
\hline $\begin{array}{l}\text { Cambissolo Háplico } \\
\text { alumínico típico (CXa) }\end{array}$ & Ponta Grossa & Paraná \\
\hline $\begin{array}{l}\text { Argissolo Vermelho distrófico } \\
\text { arênico (PVd) [1] }\end{array}$ & Umuarama & Paraná \\
\hline $\begin{array}{l}\text { Argissolo Vermelho distrófico } \\
\text { latossólico (PVd) [2] }\end{array}$ & Paranavaí & Paraná \\
\hline $\begin{array}{l}\text { Neossolo Regolítico eutrófico } \\
\text { típico (RRe) }\end{array}$ & Diamante do Sul & Paraná \\
\hline $\begin{array}{l}\text { Latossolo Vermelho } \\
\text { distroférrico típico (LVdf) [2] }\end{array}$ & Ampére & Paraná \\
\hline
\end{tabular}

$\overline{{ }^{(1)} \text { According to Embrapa (2006). For more details, see Rodak (2014). }}$

to $50 \mathrm{~mL}$ of DTPA extractant solution. Then the samples were stirred for $2 \mathrm{~h}$ at $220 \mathrm{rpm}$, after which the suspension was immediately passed through quantitative filter paper (blue band) and subjected to ICP-OES for determination of $\mathrm{Ni}$ content. DTPA solution consisted of a mixture of diethylenetriamine pentaacetic acid (DTPA $0.005 \mathrm{~mol} \mathrm{~L}^{-1}$ ), triethanolamine (TEA $0.1 \mathrm{~mol} \mathrm{~L}^{-1}$ ) and calcium chloride $\left(\mathrm{CaCl}_{2} \cdot 2 \mathrm{H}_{2} \mathrm{O} 0.01 \mathrm{~mol} \mathrm{~L}^{-1}\right)$ at $\mathrm{pH}$ 7.3, corrected with a hydrochloric acid solution ( $\left.\mathrm{HCl} 4 \mathrm{~mol} \mathrm{~L}^{-1}\right)$.

\section{Analysis of plant tissue samples}

To determine Ni concentration in the plant parts, the samples were digested with nitric acid $\left(\mathrm{HNO}_{3}\right)$ in a closed system in a Mars Xpress microwave oven (CEM), with subsequent determination by ICP-OES (Malavolta et al., 1997). To measure Ni concentrations in the plant tissue, the analytical method was optimized to 
concentrate the extract for determination. For this, $6 \mathrm{~mL}$ of $\mathrm{HNO}_{3}$ was added to $0.5 \mathrm{~g}$ of ground dry plant matter and the samples were pre-digested for $30 \mathrm{~min}$ before being placed in the microwave oven. The heating program was: 10 min to reach $170{ }^{\circ} \mathrm{C}, 15 \mathrm{~min}$ at $170{ }^{\circ} \mathrm{C}$, and $20 \mathrm{~min}$ of cooling. After the microwave digestion, the samples were diluted to $15 \mathrm{~mL}$ with ultra-pure water.

\section{RESULTS AND DISCUSSION}

The average recovery values obtained by fitting the method for plant tissue and grains were high, with values between 86.54 to $93.90 \%$ in relation to the certified values for the samples (Table 2), indicating successful Ni determination with adjustment of the method. However, the recovery values for the available levels in the soil were low, averaging $2.06 \%$ when using Mehlich-1 extraction and $0.79 \%$ with DTPA (Table 2). These recovery percentages can be explained by the fact that the method used was adjusted to measure available levels rather than total levels.
The average concentrations of available $\mathrm{Ni}$ in the soil samples varied from $<0.10$ to $1.39 \mathrm{mg} \mathrm{dm}^{-3}$ with Mehlich-1 extraction and from $<0.013$ to

Table 2. Average of reference values and recovery of certified samples used to set the methods of nickel quantification

\begin{tabular}{|c|c|c|c|}
\hline \multirow{2}{*}{ Sample } & \multicolumn{3}{|c|}{ Ni concentration } \\
\hline & Reference value & Quantified value & Recovery \\
\hline & & & $\%$ \\
\hline & \multicolumn{3}{|c|}{ Soil $\left(\mathrm{mg} \mathrm{dm}^{-3}\right)^{(1)}$} \\
\hline \multirow[t]{2}{*}{$\mathrm{BCR}^{\circledR}-142 \mathrm{R}$} & $64.5^{(2)}$ & $1.33 / 0.51$ & $2.06 / 0.79$ \\
\hline & \multicolumn{3}{|c|}{ Shoot $\left(\mathrm{mg} \mathrm{kg}^{-1}\right)$} \\
\hline $\mathrm{BCR}^{\circledR}-402$ & 8.25 & 7.17 & 86.91 \\
\hline \multirow[t]{2}{*}{$\mathrm{BCR}^{\circledR}-482$} & 2.47 & 2.14 & 86.64 \\
\hline & \multicolumn{3}{|c|}{ Grain (mg kg $\left.{ }^{-1}\right)$} \\
\hline IPE 903 & 2.13 & 2.0 & 93.90 \\
\hline IPE 192 & 1.04 & 0.9 & 86.54 \\
\hline
\end{tabular}

Table 3. Available levels of Ni extracted by DTPA and Mehlich-1 in 14 soil samples collected from the 0-20 cm layer

\begin{tabular}{|c|c|c|c|c|c|c|}
\hline \multirow{3}{*}{ Classification } & \multicolumn{6}{|c|}{ Ni concentration } \\
\hline & \multicolumn{3}{|c|}{ Mehlich-1 } & \multicolumn{3}{|c|}{ DTPA } \\
\hline & Minimum & Maximum & Average & Minimum & Maximum & Average \\
\hline & \multicolumn{6}{|c|}{$\mathrm{mg} \mathrm{dm}^{-3}$} \\
\hline & \multicolumn{6}{|c|}{ Without Ni application } \\
\hline LVAd & - & - & $<0.10$ & - & - & $<0.013$ \\
\hline LAd & - & - & $<0.10$ & - & - & $<0.013$ \\
\hline $\operatorname{LVd}[1]$ & - & - & 0.14 & - & - & 0.09 \\
\hline $\operatorname{LVd}[2]$ & - & - & 0.27 & - & - & 0.11 \\
\hline $\mathrm{LBa}$ & - & - & 0.16 & - & - & 0.08 \\
\hline \multirow[t]{2}{*}{$\operatorname{LVd}[3]$} & - & - & 0.13 & - & - & 0.07 \\
\hline & \multicolumn{6}{|c|}{ With Ni application $^{(1)}$} \\
\hline LVdf [1] & 0.44 & 1.12 & 0.75 & 0.18 & 0.54 & 0.34 \\
\hline LVef & 0.27 & 3.24 & 0.81 & 0.14 & 1.87 & 0.44 \\
\hline $\operatorname{LVd}[4]$ & $<0.10$ & 1.78 & 0.44 & $<0.013$ & 1.13 & 0.24 \\
\hline Cxa & 0.07 & 0.43 & 0.21 & 0.07 & 0.37 & 0.17 \\
\hline PVd [1] & 0.13 & 0.56 & 0.30 & 0.09 & 0.47 & 0.22 \\
\hline PVd [2] & 0.17 & 0.55 & 0.30 & 0.10 & 0.48 & 0.25 \\
\hline RRe & 0.90 & 1.41 & 1.10 & 0.64 & 1.37 & 0.94 \\
\hline LVdf [2] & 1.25 & 1.65 & 1.39 & 0.73 & 1.25 & 0.97 \\
\hline \multicolumn{7}{|c|}{$\begin{array}{l}\text { (1) Rates of 0.0, 0.2, 0.4, 0.5, 0.8, } 1.0 \text { and } 5.0 \mathrm{mg} \mathrm{dm}^{-3} \text { of Ni incorporated into the soil; LVAd - Latossolo Vermelho-Amarelo distrófico } \\
\text { típico (Balsas - MA); LAd - Latossolo Amarelo distrófico típico (Luiz Eduardo Magalhães - BA); LVd - Latossolo Vermelho distrófico } \\
\text { típico (Primavera do Leste - MT [1] and Rio Verde - GO [2]) or Latossolo Vermelho distrófico húmico (Coxilha - RS [3] and Iporã - PR } \\
\text { [4]); LBa - Latossolo Bruno alumínico típico (Campo Novo - RS); LVdf - Latossolo Vermelho distroférrico típico (Londrina [1] and } \\
\text { Ampére [2] - PR); LVef - Latossolo Vermelho eutroférrico típico (Palotina - PR); Cxa - Cambissolo Háplico alumínico típico (Ponta } \\
\text { Grossa - PR); PVd - Argissolo Vermelho distrófico arênico (Umuarama [1]) and Argissolo Vermelho distrófico latossólico (Paranava1 } \\
\text { [2] - PR); RRe - Neossolo Regolitico eutrófico típico (Diamante do Sul - PR). For more details, see Rodak (2014). }\end{array}$} \\
\hline
\end{tabular}


Table 4. Reference quality values (RQV) for nickel in the Brazilian states

\begin{tabular}{lrc}
\hline State & RQV & Literature \\
\hline & $\mathrm{mg} \mathrm{kg}^{-1}$ & \\
Minas Gerais & 21.50 & Caires (2009) \\
Espírito Santo & 9.17 & Paye et al. (2010) \\
Rondônia and Mato Grosso & 2.10 & Santos (2011) \\
São Paulo & 13.00 & Cetesb (2005) \\
Coastal plain of Paraná & 17.22 & Buschle (2013) \\
Paraná (B horizon) & 17.00 & Licht et al. (2006) \\
Conama(1) & 30.00 & Conama (2009) \\
\hline
\end{tabular}

(1) National Environmental Council of Brazil.

$0.97 \mathrm{mg} \mathrm{dm}^{-3}$ with DTPA (Table 3). In Ni fertilized soil samples, the element availability increased, to at most $3.24 \mathrm{mg} \mathrm{dm}^{-3} \mathrm{Ni}$ with Mehlich-1 and $1.87 \mathrm{mg} \mathrm{dm}^{-3}$ with DTPA. The soil samples LVAd, LAd and LVd [4] without Ni applications contained available levels below the quantification limits of $<0.10$ and $<0.013 \mathrm{mg} \mathrm{dm}^{-3}$ of Ni with Mehlich-1 and DTPA, respectively. This clearly shows the difficulty of quantifying this micronutrient, especially in natural soils.

To ensure soil quality and prevent problems of food grown on contaminated soils, the National Environmental Council of Brazil (Conama, 2009) set a deadline of 2014 to establish Reference Quality Values (RQV) for potentially toxic elements, including Ni, for each state of the country. Table 4 presents the RQV proposed to date in some Brazilian states. There are no ranges and critical values in agricultural or natural soils regarding available $\mathrm{Ni}$ concentrations, evidencing that the analysis of total levels alone is not sufficient, but that policies for available levels must be set.

Concentrations of $\mathrm{Ni}$ in the plant tissue varied from $<0.084$ to $14.26 \mathrm{mg} \mathrm{kg}^{-1}$ (Table 5). As stated for the available levels (Table 3), plants cultivated in soils without $\mathrm{Ni}$ fertilization contained the lowest levels, below the quantification limit of $<0.084 \mathrm{mg} \mathrm{kg}^{-1}$. Concentrations in soybean plants were generally higher in the leaves than shoots, but lower than in the grains, with or without $\mathrm{Ni}$ fertilization (Table 5), evidencing that plant parts differ regarding $\mathrm{Ni}$ levels. The average values found in the plant tissue in this study were within the maximum tolerance range established by the National Sanitary Surveillance Agency (Anvisa, 1965), i.e., 0.1 to $4.0 \mathrm{mg} \mathrm{kg}^{-1} \mathrm{Ni}$.

Correlations ( $\mathrm{r}$ ) between the available Ni levels in the soil and in the three plant parts were positive and significant for extraction with Mehlich-1 and DTPA (Table 6). Among the Ni levels in the shoot, leaf and grain, the correlation with the soil concentration was
Table 5. Nickel concentration in plant tissues of soybean

\begin{tabular}{lccc}
\hline \multirow{2}{*}{ Plant tissue $^{(1)}$} & \multicolumn{3}{c}{ Ni concentration } \\
\cline { 2 - 4 } & Minimum & Maximum & Average \\
\hline \multirow{3}{*}{ Leaf } & $\mathrm{mg} \mathrm{kg}^{-1}$ \\
Shoot & $<0.084$ & 3.02 & 0.58 \\
Grain & $<0.084$ & 1.49 & 0.33 \\
\hline
\end{tabular}

(1) Including samples with and without Ni application.

Table 6. Correlations between Ni in soil (Mehlich-1 and DTPA), leaf, grain and shoot of soybean plants grown in soils with different levels of this micronutrient

\begin{tabular}{lcccc}
\hline & DTPA & Shoot & Grain & Leaf \\
\hline Mehlich-1 & $0.95^{* *}$ & $0.10^{\mathrm{ns}}$ & $0.91^{* *}$ & $0.47^{* *}$ \\
DTPA & - & $0.11^{\mathrm{ns}}$ & $0.91^{* *}$ & $0.53^{* *}$ \\
Shoot & - & - & $0.90^{* *}$ & $0.14^{\mathrm{ns}}$ \\
Grain & - & - & - & $0.47^{* *}$ \\
\hline
\end{tabular}

Including samples with and without $\mathrm{Ni}$ application; ${ }^{* *}$ and ${ }^{n s}$ : significant and non-significant at $\mathrm{p}<0.01$ by the Pearson correlation coefficient.

highest in the latter, by both extractants. The less significant correlation for leaf in relation to grains levels can be related to the mobility of $\mathrm{Ni}$ in plant tissue. Findings of Cataldo et al. (1978) confirm this assumption. They observed that $70 \%$ of the $\mathrm{Ni}$ present in soybean leaves in the senescent state was remobilized from the leaf tissue to the grains.

\section{CONCLUSIONS}

The tested methods were successful in quantifying $\mathrm{Ni}$ and can be used in laboratories for routine analysis of soil and plant tissue samples. There was a positive and significant correlation between the available $\mathrm{Ni}$ levels extracted from the soil with Mehlich-1 and DTPA; in the plant tissue the recovered levels were high in relation to the corresponding certified samples.

Nickel availability in some natural soil and plant tissue samples were lower than the quantification limit.

Nickel concentrations were higher in the soil samples that had received $\mathrm{Ni}$ fertilization.

Nickel levels differed in the plant parts, and were highest in the grains.

Correlations between Ni levels in the grains and available levels in the soil extracted with Mehlich-1 and DPTA were stronger than the correlations with $\mathrm{Ni}$ levels in shoot and leaves. 


\section{ACKNOWLEDGEMENTS}

The authors are indebted to the Graduate Program of Soil Science of the Federal University of Paraná - UFPR; to the Coordination for the Improvement of Higher Education Personnel, CAPES, and to Embrapa Soybean, especially to the technicians Mr. Joviano Kleinert and Ms. Mariana Germano; to the Prof. Dr. Luiz Roberto G. Guilherme for provide samples of certified reference materials; to Dr.a Aline R. Coscione for the suggestions on digestion of plant tissues.

\section{REFERENCES}

Agência Nacional Vigilância Sanitária - Anvisa. Decreto $\mathrm{N}^{\circ}$ 55.871 , de 26 de março de 1965. Modifica o Decreto $\mathrm{N}^{\circ} 50.040$, de 24 de janeiro de 1961, referente a normas reguladoras do emprego de aditivos para alimentos, alterado pelo Decreto $\mathrm{N}^{\circ} 691$, de 13 de março de 1962. São Paulo: Anvisa; 1965.

Brasil. Ministério da Agricultura, Pecuária e Abastecimento. Instrução Normativa MAPA 5/2007 (D.O.U. 01/03/2007). [Acessado em 24 fev 2014]. Disponível em: http://sistemasweb.agricultura. gov.br/sislegis/action/detalhaAto.do? $\operatorname{method}=$ recuperar TextoAtoTematicaPortal\&codigoTematica $=1229260$.

Brooks RR. Accumulation of nickel by terrestrial plants. In: Nriagu JO, editor. Nickel in the environment. New York: Wiley \& Sons; 1980. p.407-30.

Brown PH, Welch RM, Cary EE. Nickel: A micronutrient essential for higher plants. Plant Physiol. 1987:85:801-3.

Buschle BN. Valores de referência de qualidade para elementos-traço em solos da Planície Litorânea do Estado do Paraná [dissertação]. Curitiba: Universidade Federal do Paraná; 2013.

Caires SM. Determinação dos teores naturais de metais pesados em solos do Estado de Minas Gerais como subsídio ao estabelecimento de Valores de Referência de Qualidade [tese]. Viçosa, MG: Universidade Federal de Viçosa; 2009.

Cataldo DA, Garland TR, Wildung RE. Nickel in plants: II. Distribution and chemical form in soybean plants. Plant Physiol. 62:566-70, 1978 .

Companhia de Tecnologia de Saneamento Ambiental - Cetesb. Decisão de diretoria $\mathrm{N}^{\circ}$ 195-2005-E, de 23 de novembro de 2005. Dispõe sobre a aprovação dos valores orientadores para solos e águas subterrâneas no estado de São Paulo - 2005, em substituição aos valores orientadores de 2001, e dá outras providências. São Paulo: 2005.

Conselho Nacional do Meio Ambiente - Conama. Resolução $\mathrm{N}^{\circ} 420$ de 28 de dezembro de 2009. Dispõe sobre critérios e valores orientadores de qualidade do solo quanto à presença de substâncias químicas e estabelece diretrizes para o gerenciamento ambiental de áreas contaminadas por essas substâncias em decorrência de atividades antrópicas. Diário Oficial da União, Poder Executivo, Brasília, DF: n.249, 2009. p.81-4.

Dixon NE, Gazzola C, Blakeley RL, Zerner B. Jack bean urease (EC 3.5.1.5) a metalloenzyme: simple biological role for nickel. J Am Chem Soc. 1975;97:4131-3.

Empresa Brasileira de Pesquisa Agropecuária - Embrapa. Manual de análises químicas de solos, plantas e fertilizantes. $2^{\text {a }}$.ed. Brasília: Embrapa Informações Tecnológicas; 2009.

Empresa Brasileira De Pesquisa Agropecuária - Embrapa. Sistema brasileiro de classificação de solos. $2^{a}$.ed. Rio de Janeiro: Embrapa Solos; 2006.

Eskew DL, Welch RM, Cary EE. Nickel: An essential micronutrient for legumes and possibly all higher-plants. Science. 1983;222:621-3.

Eskew DL, Welch RM, Norvell WA. Nickel in higher plants: further evidence for an essential role. Plant Physiol. 1984;76:691-3.

Freschi GPG, Dakuzaku CS, Gomes Neto JA, Moraes M. Espectrometria de absorção atômica multielementar simultânea com atomização eletrotérmica em forno de grafite - uma revisão técnica e aplicações. Eclet Quím. 2000;25:[online]

Licht OAB, Xuejing X, Qin Z, Miyazawa M, Ferreira FJF, Plawiak $\mathrm{RAB}$. Average reference values of geochemical and geophysical variables in stream sediments and soils, state of Paraná, Brazil. B. Paranaense Geoci. 2006;58:59-87.

Liu L, Ge W, Bestel S, Jones D, Shi J, Song Y, Chen X. Plant exploitation of the last foragers at Shizitan in the Middle Yellow River Valley China: Evidence from grinding stones. J Archaeol Sci. 2011;38:3524-32.

Malavolta E, Vitti GC, Oliveira SA. Avaliação do estado nutricional das plantas: Princípios e aplicações. $2^{\mathrm{a}}$.ed. Piracicaba: Potafos; 1997.

Paye HS, Mello JWV, Abrahão WAP, Fernandes Filho EI, Dias LCP, Castro MLO, Melo SB, França MM. Valores de referência de qualidade para metais pesados em solos no Estado do Espírito Santo. R Bras Ci Solo. 2010;34:2041-51.

Raij Bvan, Andrade JC, Cantarella H, Quaggio JA. Análise química para avaliação da fertilidade de solos tropicais. Campinas: Instituto Agronômico de Campinas; 2001.

Rodak BW. Níquel em solos e na cultura de soja [dissertação]. Curitiba: Universidade Federal do Paraná; 2014.

Santos SN. Valores de referência de metais pesados em solos de Mato Grosso e Rondônia [dissertação]. Piracicaba: Universidade de São Paulo; 2011.

Stat Soft. Software Statistica 7. 2004. [Acessado em 24 nov 2014]. Disponível em: http://www.statsoft.com.br/pt-BR/.

Uren NC. Forms, reaction and availability of nickel in soils. Adv Agron. 1992;48:141-203.

Vanselow AP. Nickel. In: Chapman HD, editor. Diagnostic criteria for plants and soils. Riverside: University of California; 1966. p.302-9.

Welch RM. The biological significance of nickel. J Plant Nutr. 1981;3:345-56. 